\title{
Effects of Dietary PCB and Caffeine on Serum and Liver Lipids and Urinary Ascorbic Acid in Rats after Different Times ${ }^{\dagger}$
}

\author{
Salamatullah QuAzI, Masahiro TaKaHata, Hidehiko YoKogoshI \\ and Akira YoshidA \\ Laboratory of Nutritional Biochemistry, \\ Department of Agricultural Chemistry, \\ Nagoya University, Nagoya 464, Japan
}

Received December 26, 1983

\begin{abstract}
Comparison of the effects of dietary PCB $(0.03 \%)$ and caffeine $(0.3 \%)$ on serum and liver lipids, and urinary ascorbic acid was done after different times. Serum total cholesterol, liver total lipids and triglyceride (TG) were found to continuously increase at 2,4 , and 8 weeks, but urinary ascorbic acid, serum TG and liver phospholipids were elevated up to 4 weeks in the PCB-fed rats. Liver cholesterol showed a decreasing trend after 2 weeks. On the other hand, dietary caffeine continuously increased serum cholesterol up to 8 weeks. Urinary ascorbic acid remained the same throughout the experimental period, but was significantly higher than in the respective controls at all times. Serum TG also remained the same, but was lower than in the respective controls. Liver total lipids, cholesterol and TG did not change in the caffeine-fed animals. The results clearly indicate that dietary PCB increased all the parameters investigated whereas caffeine elevated serum cholesterol and urinary ascorbic acid, but depressed the serum TG concentration.
\end{abstract}

Recently we and other workers reported that the administration of polychlorinated biphenyls (PCB), 1,1,1-trichloro-2,2-bis ( $p$ chlorophenyl)ethane (DDT), butylated hydroxytoluene, chloretone and other xenobiotics caused a fatty liver, hyperchlolesterolemia, increased urinary ascorbic acid and induction of the activities of liver microsomal mixed function oxidase systems in rats. ${ }^{1 \sim 5)}$ These experiments were conducted mostly for 3 weeks. On the other hand, contradictory results have been obtained concerning the effects of caffeine or caffeine-containing beverages on serum cholesterol and triglyceride (TG) in humans and animals. Myasnikov $\left.{ }^{6}\right)$ found that caffeine increased serum cholesterol but Naismith et al. ${ }^{7}$ demonstrated the opposite in humans. Again, with increasing intake of caffeine, the plasma cholesterol and phospholipid concentrations rose, while the TG concentration fell in rats. ${ }^{8)}$ Fears ${ }^{9}$ reported that after 7 days caffeine- $(2.5 \mathrm{~g} / \mathrm{kg})$ feeding serum cholesterol had significantly increased, but the value was the same as the control at 25 days. Recently, Srimathi et al. ${ }^{10)}$ showed that serum cholesterol did not change, but the TG level decreased in 20 days coffeefed rats. We previously reported that dietary addition of instant coffee, black tea, green tea (containing about $0.35 \%$ caffeine), cocoa (containing about $0.35 \%$ theobromine) and also $0.3 \%$ caffeine significantly increased serum cholesterol in rats fed for 2 weeks. ${ }^{11)}$ Thus the results so far reported as to the effect of caffeine or caffeine-containing beverages on serum lipids are not necessarily consistent.

In the experiment reported here, we compared the effects of dietary PCB and caffeine on serum and liver lipids, and urinary ascorbic acid in rats at different times for a longer period. Also a detailed investigation of the liver total lipids, cholesterol, phospholipid and TG was conducted in the caffeine-fed rats. As both PCB and caffeine are known to increase

$\dagger$ Supported by a grant from the Ministry of Education, the Nissan Science Foundation, and the Vitamin C Research Committee in Japan. 
the activity of liver mixed function oxidase systems, the comparison was made to obtain common information about the control of lipid metabolism and urinary ascorbic acid by xenobiotics and caffeine.

\section{MATERIALS AND METHODS}

Animals and diets. Male rats of the Wistar strain weighing on average $89 \sim 90 \mathrm{~g}$ (at the time of the test diets) were used. They were fed a commercial stock diet (CE-2, Japan Clea Co., Ltd., Tokyo) for 3 days and then offered an adequate $25 \%$ casein diet for 2 days before test diets were provided. The composition of the basal diet was, by percentage: casein, 20; salt mixture, ${ }^{12)} 5$; vitamin mixture, ${ }^{12)} 1.7$; choline chloride, 0.2 ; corn oil, 2 ; and a mixture of sucrose and starch $(1: 2)$ was added to make up $100 \%$. Retinyl palmitate, ergocalciferol and $d l$ - $\alpha$-tocopheryl acetate were added at concentrations of $1800 \mathrm{IU}, 4.5 \mu \mathrm{g}$ and $10 \mathrm{mg}$ per $100 \mathrm{~g}$ of the diet, respectively. In the experimental diets, $300 \mathrm{ppm}$ PCB (Aroclor 1248, Mitsubishi Monsant Co., Ltd., Tokyo) or $3000 \mathrm{ppm}$ caffeine (Katayama Chemical Co.) was added at the expence of carbohydrate. Retinyl palmitate and ergocalciferol were used in large amounts because of the 8 week experimental period. All rats were individually housed and diets and tap water were supplied ad libitum. The room temperature was kept at $22 \pm 2^{\circ} \mathrm{C}$ with a $12 \mathrm{hr}$ cycle of light $(0800 \sim 2000 \mathrm{hr})$ and dark. On the last day of the experimental periods $(0,2,4$ and 8 weeks), the diet was removed from the individual cages at $0900 \mathrm{hr}$. Rats were anesthetized with diethyl ether and killed at $1300 \mathrm{hr}$ within a short period. Blood was collected by cardiac puncture for serum lipids analysis. The liver was removed, weighed and then stored at $-20^{\circ} \mathrm{C}$ untill liver lipids were analyzed.

Analytical methods. On days 9 10, 29 30, 44 45 and $51 \sim 52$, urine was collected for $24 \mathrm{hr}$ in $25 \mathrm{ml}$ of a $5 \%$ metaphosphoric acid solution, filtered and used for determination of ascorbic acid. Ascorbic acid was measured by the 2,4-dinitrophenylhydrazine method. ${ }^{13)}$ The liver total lipids were extracted by the method of Folch et al. ${ }^{14)}$ and used for determination of cholesterol, triglyceride and phospholipid. Cholesterol in the serum and liver was measured by the method of Pearson et al. ${ }^{15)}$ Serum triglyceride was measured with a commercially available kit (triglyceride fully enzymatic UV-method, Test-Combination, Boehringer Mannheim, West Germany) according to the method of Wahlfeld. ${ }^{16)}$ Total lipid phosphorous was determined by the method of Bartlett, ${ }^{17)}$ and the values were multiplied by 25 to obtain the phospholipid content of the liver. Liver TG was calculated from liver total lipids minus liver chlolesterol and phospholipid.

The data were analyzed statistically by the analysis of variance and mean compared using Duncan's multiplerange test. ${ }^{18)}$

\section{RESULTS}

Changes in body weight were measured daily for all rats, but data are shown graphically only for the rats fed the experimental diets up to 8 weeks (Fig. 1). On the first day, the body weight of the caffeine-fed rats decreased and then increased at a slower rate as compared to both control and PCB-fed rats (Fig. 1). At the end of the experimental period, the body weight gain was still significantly $(p<0.05)$ lower in the caffeine-fed group (Table I). On the other hand, there were no significant differences in body change found between the control and PCB-fed animals throughout the experimental period. Food intake (data not shown) was also measured at several times. On the first day of the experimental period, the food intake of the rats fed the caffeine-containing diet was significantly lower as compared to the control and PCB-fed rats and then gradually increased. From day 28 onward, the food intake of the caffeine-fed group was still lower but statistically not significantly $(p<0.05)$ as compared to the other two groups (control and PCB), respectively. No significant differences were observed in food intake between the control and PCB-fed rats throughout the experimental period. A

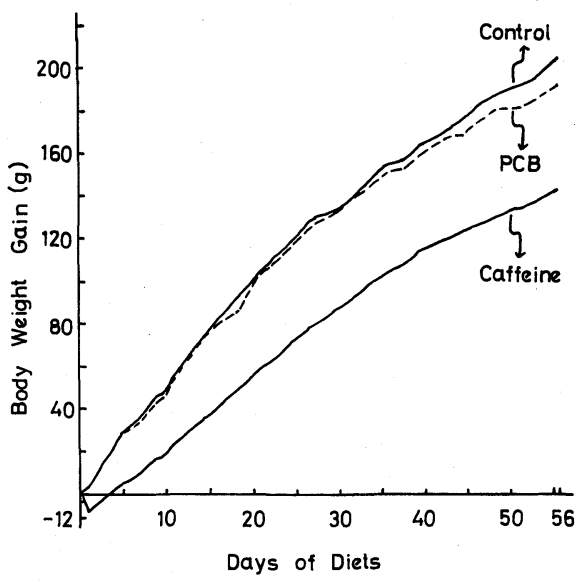

FIG. 1. Changes in Body Weight Gain of Rats Fed a Diet Containing either PCB or Caffeine. 
Table I. Comparison of the Effects of Dietary PCB and Caffeine ON BODY Weight Gain and Liver Weight aT

DIFFERENT TIMES IN RATS ${ }^{1}$

\begin{tabular}{|c|c|c|c|c|}
\hline \multirow{2}{*}{$\begin{array}{l}\text { Dietary } \\
\text { groups }\end{array}$} & \multirow{2}{*}{$\begin{array}{l}\text { Feeding } \\
\text { periods } \\
\text { (weeks) }\end{array}$} & \multirow{2}{*}{$\begin{array}{l}\text { Body wt. } \\
\text { gain } \\
\text { (g) }\end{array}$} & \multicolumn{2}{|c|}{ Liver weight } \\
\hline & & & (g) & ( $\%$ of body wt.) \\
\hline A. Basal & $\begin{array}{l}0 \\
2 \\
4 \\
8\end{array}$ & $\begin{array}{c}- \\
73.8 \pm 1.5^{2,3 \mathrm{~d}} \\
137.3 \pm 2.4^{\mathrm{bc}} \\
203.1 \pm 3.7^{\mathrm{a}}\end{array}$ & $\begin{array}{r}3.86 \pm 0.06^{\mathrm{h}} \\
7.72 \pm 0.15^{\mathrm{f}} \\
9.82 \pm 0.18^{\mathrm{d}} \\
11.48 \pm 0.37^{\mathrm{c}}\end{array}$ & $\begin{array}{l}4.31 \pm 0.04^{\mathrm{de}} \\
4.72 \pm 0.06^{\mathrm{c}} \\
4.33 \pm 0.09^{\mathrm{de}} \\
3.91 \pm 0.07^{\mathrm{f}}\end{array}$ \\
\hline $\begin{array}{l}\text { B. } \mathrm{A}+0.03 \% \\
\quad \text { PCB }\end{array}$ & $\begin{array}{l}2 \\
4 \\
8\end{array}$ & $\begin{array}{r}67.7 \pm 2.2^{\mathrm{d}} \\
125.0 \pm 3.1^{\mathrm{c}} \\
190.3 \pm 3.2^{\mathrm{a}}\end{array}$ & $\begin{array}{l}10.56 \pm 0.25^{\mathrm{d}} \\
14.12 \pm 0.25^{\mathrm{b}} \\
16.94 \pm 0.23^{\mathrm{a}}\end{array}$ & $\begin{array}{l}6.71 \pm 0.12^{\mathrm{a}} \\
6.57 \pm 0.05^{\mathrm{a}} \\
6.04 \pm 0.05^{\mathrm{b}}\end{array}$ \\
\hline $\begin{array}{c}\text { C.A }+0.3 \% \\
\text { Caffeine }\end{array}$ & $\begin{array}{l}2 \\
4 \\
8\end{array}$ & $\begin{array}{r}30.4 \pm 5.9^{\mathrm{e}} \\
76.8 \pm 4.9^{\mathrm{d}} \\
141.6 \pm 4.4^{\mathrm{b}}\end{array}$ & $\begin{array}{l}5.54 \pm 0.55^{\mathrm{g}} \\
7.07 \pm 0.37^{\mathrm{f}} \\
8.87 \pm 0.33^{\mathrm{e}}\end{array}$ & $\begin{array}{l}4.56 \pm 0.23^{\mathrm{cd}} \\
4.23 \pm 0.10^{\mathrm{e}} \\
3.84 \pm 0.06^{\mathrm{f}}\end{array}$ \\
\hline
\end{tabular}

${ }^{1}$ Initial average body weight was $89 \sim 90$ g. ${ }^{2}$ Means \pm S.E.M.; $n=6 .{ }^{3}$ Means within a column not followed by the same letter are significantly different $(p<0.05)$.

similar pattern of body weight gain was also observed among the dietary groups at 2 and 4 weeks of the experimental period, respectively (Table I).

Total liver weight and liver weight expressed as $\%$ of the body weight are also shown in Table I. Total liver weight was always significantly higher in the PCB-fed rats and lower in the rats fed the caffeine-containing diet as compared to the respective controls at 2,4 , and 8 weeks of the experimental period. On the other hand, there were no significant differences observed in liver weight per unit body weight between the control and caffeine-fed rats at different times. The serum TG concentration continuously increased up to 4 weeks in the PCB-fed rats and was always higher $(p<0.05)$ than in the respective controls and caffeine-fed animals (Fig. 2). Conversely, the level was lower in the rats fed caffeine even compared with the controls at different times.

Again, serum total cholesterol continuously increased in both PCB and caffeine-fed animals up to the end of the experimental period (8 weeks), although it was always higher in the rats fed PCB (Fig. 2).

Urinary ascorbic acid levels in the PCB and caffeine-fed rats at different times are shown in Fig. 3. Urinary ascorbic acid was found to

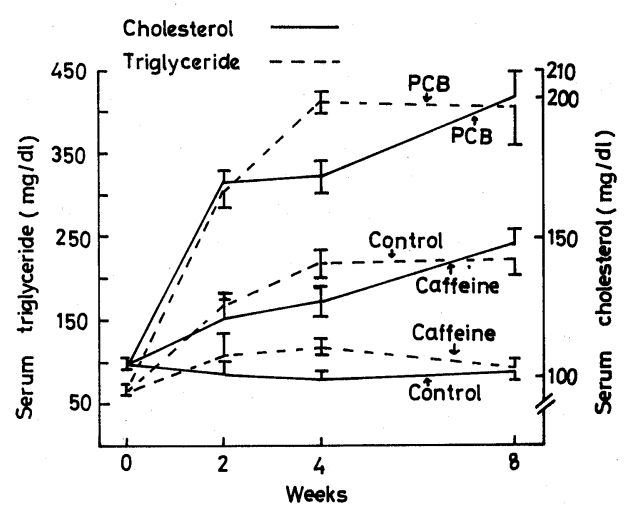

FIG. 2. Comparison of the Effects of Dietary PCB and Caffeine on Serum Cholesterol and Triglyceride in Rats. Vertical bars indicate standard errors.

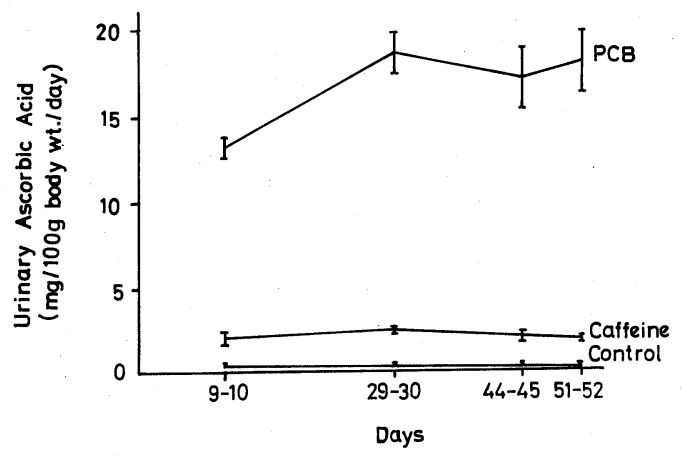

FIG. 3. Comparison of the Effects of Dietary PCB and Caffeine on Urinary Ascorbic Acid in Rats.

Vertical bars indicate standard errors. 
Table II. Comparison of the Effects of Dietary PCB and Caffeine on Liver LIPIDS AT DIFFERENT TIMES IN RATS ${ }^{1}$

\begin{tabular}{|c|c|c|c|c|c|c|c|c|c|}
\hline \multirow{3}{*}{$\begin{array}{l}\text { Dietary } \\
\text { groups }\end{array}$} & \multirow{3}{*}{$\begin{array}{l}\text { Feeding } \\
\text { periods } \\
\text { (weeks) }\end{array}$} & \multicolumn{8}{|c|}{ Liver } \\
\hline & & \multicolumn{2}{|c|}{ Total lipids } & \multicolumn{2}{|c|}{ Cholesterol } & \multicolumn{2}{|c|}{ Phospholipid } & \multicolumn{2}{|c|}{ Triglyceride } \\
\hline & & $\mathrm{mg} / \mathrm{g}$ tissue & $\mathrm{mg} / 100 \mathrm{~g}$ body wt. & $\mathrm{mg} / \mathrm{g}$ tissue & $\mathrm{mg} / 100 \mathrm{~g}$ body wt. & $\mathrm{mg} / \mathrm{g}$ tissue & $\mathrm{mg} / 100 \mathrm{~g}$ body wt. & $\mathrm{mg} / \mathrm{g}$ tissue & $\mathrm{mg} / 100 \mathrm{~g}$ body wt. \\
\hline \multirow[t]{4}{*}{ A. Basal } & 0 & $55.6 \pm 2.5^{2,3 \mathrm{c}}$ & $239.8 \pm 11.1^{\mathrm{c}}$ & $6.8 \pm 0.3^{b}$ & $29.3 \pm 1.4^{\mathrm{bcd}}$ & $34.7 \pm 0.5^{\mathrm{c}}$ & $149.8 \pm 3.1^{\mathrm{cd}}$ & $14.1 \pm 2.3^{\text {cd }}$ & $60.7 \pm 9.6^{\text {cde }}$ \\
\hline & 2 & $44.4 \pm 0.6^{\mathrm{e}}$ & $209.4 \pm 2.6^{c}$ & $5.6 \pm 0.4^{\mathrm{cd}}$ & $26.6 \pm 1.6^{\text {cde }}$ & $31.7 \pm 0.5^{\mathrm{f}}$ & $149.5 \pm 2.3^{\text {cd }}$ & $7.1 \pm 0.9^{\text {ef }}$ & $33.3 \pm 4.4^{\mathrm{e}}$ \\
\hline & 4 & $53.7 \pm 0.8^{\mathrm{c}}$ & $232.3 \pm 7.6^{\mathrm{c}}$ & $5.9 \pm 0.4^{b c}$ & $25.6 \pm 1.9^{\mathrm{de}}$ & $32.5 \pm 0.4^{\mathrm{ef}}$ & $140.5 \pm 2.5^{\mathrm{d}}$ & $15.3 \pm 0.7^{\mathrm{cd}}$ & $66.3 \pm 4.4^{\text {cde }}$ \\
\hline & 8 & $59.3 \pm 2.8^{c}$ & $231.8 \pm 12.3^{\mathrm{c}}$ & $4.3 \pm 0.3^{\mathrm{e}}$ & $16.7 \pm 1.0^{\mathrm{f}}$ & $31.4 \pm 0.4^{\mathrm{f}}$ & $122.7 \pm 3.0^{\mathrm{e}}$ & $23.6 \pm 3.0^{\mathrm{b}}$ & $92.4 \pm 12.3^{\mathrm{c}}$ \\
\hline \multirow{3}{*}{$\begin{array}{l}\text { B. } A+0.03 \% \\
\quad \text { PCB }\end{array}$} & 2 & $66.6 \pm 3.2^{\mathrm{b}}$ & $448.8 \pm 29.1^{\mathrm{b}}$ & $8.3 \pm 0.2^{\mathrm{a}}$ & $55.8 \pm 1.5^{\mathrm{a}}$ & $38.6 \pm 0.3^{b}$ & $259.1 \pm 5.4^{\mathrm{a}}$ & $19.7 \pm 3.3^{\mathrm{bc}}$ & $133.9 \pm 24.4^{\mathrm{b}}$ \\
\hline & 4 & $68.8 \pm 0.9^{b}$ & $452.2 \pm 5.4^{b}$ & $4.9 \pm 0.3^{\text {cde }}$ & $32.1 \pm 1.7^{\mathrm{b}}$ & $40.4 \pm 0.3^{\mathrm{a}}$ & $265.4 \pm 2.5^{\mathrm{a}}$ & $23.6 \pm 0.7^{b}$ & $154.7 \pm 4.0^{\mathrm{b}}$ \\
\hline & 8 & $83.9 \pm 3.4^{\mathrm{a}}$ & $506.7 \pm 21.8^{\mathrm{a}}$ & $5.0 \pm 0.3^{\text {cde }}$ & $30.4 \pm 2.1^{\mathrm{bcd}}$ & $38.5 \pm 0.4^{b}$ & $232.3 \pm 1.8^{\mathrm{b}}$ & $40.4 \pm 3.1^{\mathrm{a}}$ & $244.0 \pm 19.3^{\mathrm{a}}$ \\
\hline \multirow{3}{*}{$\begin{array}{c}\text { C.A }+0.3 \% \\
\text { Caffeine }\end{array}$} & 2 & $47.4 \pm 1.5^{\mathrm{de}}$ & $216.9 \pm 15.9^{c}$ & $6.8 \pm 0.3^{b}$ & $30.8 \pm 0.7^{\mathrm{bc}}$ & $34.4 \pm 0.8^{\mathrm{cd}}$ & $156.1 \pm 5.3^{c}$ & $6.1 \pm 2.1^{\mathrm{f}}$ & $30.0 \pm 11.4^{\mathrm{e}}$ \\
\hline & 4 & $53.1 \pm 1.8^{\mathrm{cd}}$ & $224.8 \pm 11.8^{\mathrm{c}}$ & $5.6 \pm 0.4^{\mathrm{cd}}$ & $23.8 \pm 2.1^{\mathrm{e}}$ & $34.8 \pm 0.4^{\mathrm{c}}$ & $147.0 \pm 4.2^{\mathrm{cd}}$ & $12.7 \pm 1.6^{\mathrm{de}}$ & $54.0 \pm 7.8^{\mathrm{de}}$ \\
\hline & 8 & $58.4 \pm 0.6^{\mathrm{c}}$ & $224.4 \pm 5.0^{\mathrm{c}}$ & $4.8 \pm 0.3^{\mathrm{de}}$ & $18.5 \pm 1.4^{\mathrm{f}}$ & $33.3 \pm 0.6^{\mathrm{de}}$ & $127.7 \pm 2.3^{\mathrm{e}}$ & $20.4 \pm 1.1^{\mathrm{bc}}$ & $78.2 \pm 4.8^{\mathrm{cd}}$ \\
\hline
\end{tabular}

$1,2,3$ Same as in Table I. 
significantly increase up to $29 \sim 30$ days in the PCB-fed rats and then remained the same untill $51 \sim 52$ days. In the caffeine-fed animals, it remained the same all the time, but was statistically higher $(p<0.05)$ than that of the controls and lower than that of the rats fed PCB.

Liver total lipids, cholesterol, phospholipid and TG values, both as $\mathrm{mg} / \mathrm{g}$ tissue and $\mathrm{mg} /$ $100 \mathrm{~g}$ body weight, are shown in Table II. Liver total lipids and TG levels continuously increased up to 8 weeks of the dietary treatment in the PCB-fed rats and were always significantly higher than in the respective controls $(p<0.05)$. But liver cholesterol up to 4 weeks and phospholipid up to 2 weeks increased and then there was a decreasing trend untill the end of the experimental period ( 8 weeks). The results are almost the same on both a $\mathrm{mg} / \mathrm{g}$ tissue and a $\mathrm{mg} / 100 \mathrm{~g}$ body weight basis. In contrast, liver total lipids and TG concentrations did not differ significantly between the caffeine-fed and control rats at 2, 4, and 8 weeks of the dietary treatment with both ways of expressing the results. Liver cholesterol was found to be elevated at 2 weeks as $\mathrm{mg} / \mathrm{g}$ tissue, but did not significantly as $\mathrm{mg} / 100 \mathrm{~g}$ body weight $(p<0.05)$. From 2 weeks there was a decreasing trend up to 8 weeks. Liver phospholipid was significantly higher than in the respective controls at different times, but the level remained the same up to 8 weeks as $\mathrm{mg} / \mathrm{g}$ tissue. No significant differences were found on a $\mathrm{mg} /$ $100 \mathrm{~g}$ body weight basis compared to the respective controls at different times.

\section{DISCUSSION}

Supplementation of caffeine to the diet depressed the growth rate. On the first day, the body weight decreased and then slowly increased. The food intake also showed the same pattern. Akinyanju and Yudkin ${ }^{19)}$ showed that caffeine-containing tea or coffee feeding in rats caused a transitory halt in weight gain during the first 3 days, which then increased. On the other hand, there were no significant differ- ences in body weight gain or food intake observed in PCB-fed rats compared to control animals.

The increase in serum total cholesterol and TG, urinary ascorbic acid, and liver lipids accompanied by the enlargement of the liver in PCB-fed rats confirmed our previous observations $^{3,5,20,21)}$ for 3 weeks, and further showed that PCB-feeding continuously increased serum total cholesterol, liver total lipids and TG at leased up to 8 weeks. In contrast, the liver cholesterol level shows a decreasing trend after 2 weeks. The same pattern was also observed in the case of controls. The reason is unknown. Kato and Yoshida ${ }^{22)}$ found striking stimulation of the liver microsomal cholesterol-synthesizing system including HMGCoA reductase activity due to 6 days PCBfeeding in rats, but could not find any difference in the enzyme activity as compared to controls in the 4 weeks PCB-fed rats (unpublished results). On the other hand, the serum cholesterol concentration was still continuously elevated. It seems likely that after a few days the effect of PCB on the cholesterol synthesizing system is minimized, but the liver continues transportation of cholesterol to the blood. As a result, liver cholesterol might be decreased. Nevertheless, the plasma cholesterol concentration is not only affected by the hepatic cholesterol synthetic rate but also by cholesterol catabolism, excretion, transport, tissue uptake and output. A similar assumption may be ture in the case of caffeine-fed animals. The increase in the urinary ascorbic acid in both PCB and caffeine-fed rats indicates an increase in ascorbic acid synthesis in rats, suggesting that dietary addition of $\mathrm{PCB}$ or caffeine might increase the ascorbic acid requirement in rats.

The increase in serum cholestrol and decrease in serum TG in the caffeine-fed animals are in agreement with the results of Naismith et al. ${ }^{8)}$ Previously we also reported that caffeine or caffeine-containing beverages significantly increased serum cholesterol but depressed the elevation of the serum TG level. Our results as to a lower TG concentration 
were also supported by Fears, ${ }^{9)}$ but not as to serum cholesterol, he found that serum cholesterol significantly increased in 7 days but the value was the same as the controls in 25 days caffeine-fed rats. In our present experiment, the liver phospholipid ( $\mathrm{mg} / \mathrm{g}$ tissue) level was significantly increased in rats fed caffeine. Naismith et al. ${ }^{8)}$ reported elevation of serum phospholipid in caffeine-fed rats. On the other hand, liver total lipids, cholesterol and TG concentrations were not affected by caffeine administration.

It is concluded that PCB-feeding increased all the parameters investigated, and there are similarities between PCB and caffeine in terms of their effects on serum cholesterol and urinary ascorbic acid, but the reverse for TG metabolism even in long terms of the feeding period.

\section{REFERENCES}

1) N. Kato and A. Yoshida, Agric. Biol. Chem., 43, 191 (1979).

2) N. Kato, M. Kato, T. Kimura and A. Yoshida, Nutr. Rep. Int., 18, 437 (1978).

3) S. Quazi, H. Yokogoshi and A. Yoshida, J. Nutr., 113, 1109 (1983).

4) A. H. Conney and J. J. Burns, Nature, 184, 363
(1959).

5) N. Kato and A. Yoshida, Nutr. Rep. Int., 23, 825 (1981).

6) A. L. Myasnikov, Circulation, 17, 99 (1958).

7) D. J. Naismith, P. A. Akinyanju, S. Szanto and J. Yudkin, Nutr. Metab., 12, 144 (1970).

8) D. J. Naismith, P. A. Akinyanju and J. Yudkin, J. Nutr., 97, 375 (1969).

9) R. Fears, Br. J. Nutr., 39, 363 (1978).

10) V. Srimathi, P. B. Seshagiri, R. Raju and S. Ramakrishnan, The Ind. J. Nutr. Dietet., 18, 360 (1981).

11) H. Yokogoshi, S. Mochizuki, M. Takahata, S. Quazi and A. Yoshida, Nutr. Rep. Int., 28, 805 (1983).

12) A. E. Harper, J. Nutr., 68, 405 (1959).

13) T. Ohara, "Shokuhinbunseki Handbook," Kenpaku Co., Tokyo, Japan, 1973, p. 301.

14) J. Folch, M. Lees and G. H. Sloane-Stanley, J. Biol. Chem., 226, 497 (1957).

15) S. Pearson, S. Stern and T. H. McGavack, Anal. Chem., 25, 813 (1953).

16) A. W. Wahlfeld, "Methods of Enzymatic Analysis," ed. by H. U., Bergmeyer, Vol. 4, Academic Press, New York, 1974, pp. $1831 \sim 1935$.

17) G. R. Bartlett, J. Biol. Chem., 234, 466 (1959).

18) D. B. Duncan, Biometrics, 11, 1 (1955).

19) P. Akinyanju and J. Yudkin, Nature, 214, 426 (1967).

20) N. Kato, T. Tani and A. Yoshida, J. Nutr., 110, 1686 (1980).

21) N. Kato, T. Tani and A. Yoshida, J. Nutr., 111, 123 (1981).

22) N. Kato and A. Yoshida, Nutr. Rep. Int., 21, 107 (1980). 